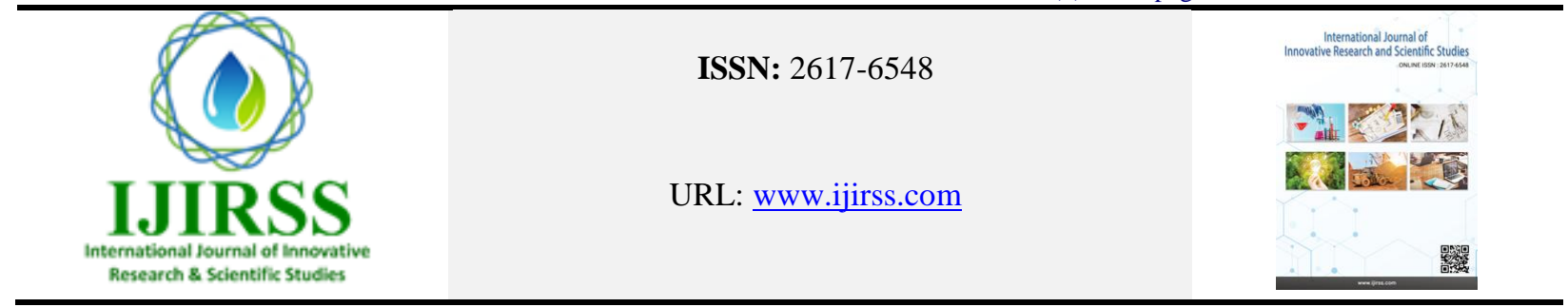

\title{
Evaluation of Nitrogen (Urea) on Zea mays L. under Balkh Province Climate
}

\author{
Nasratullah Habibi ${ }^{1 *}$, Friba Sikandari ${ }^{2}$ \\ ${ }^{1,2}$ Faculty of Agriculture, Balkh University, Balkh, Afghanistan \\ *Corresponding author: Nasratullah Habibi (nasratullah.habibi14@gmail.com)
}

\begin{abstract}
An experiment was conducted to evaluate effect of urea fertilizer on yield and yield components of Zea mays L. Using Randomized Complete Block Design (RCBD) split plots in three replications in agricultural research farm of Balkh University by 2019. Doses of urea used in this experiment were $0,80,160$ and $240 \mathrm{~kg} \mathrm{ha}^{-1}$, respectively. It has been found that amount of nitrogen fertilizer (urea) had significant effect on yield of maize at $\mathrm{p}<0.05$. The higher level of nitrogen caused the higher grain yield, number of kernels per ear, the number of grains per ear row, ear diameter, cob length, grain per plant and plant height. As a result 7.76 ton $\mathrm{ha}^{-1}$ was recorded as high yield while $240 \mathrm{~kg} \mathrm{ha}^{-1}$ urea was used, and 5.12 ton $\mathrm{ha}^{-1}$ was recorded as low yield in treatment one with $0 \mathrm{~kg} \mathrm{ha}^{-1}$ of nitrogen fertilizer. Finally, as a result using $240 \mathrm{~kg}^{-1}$ nitrogen fertilizer is recommended.
\end{abstract}

Keywords: Maize, Nitrogen, Urea, Yield, Yield components.

DOI: 10.53894 /ijirss.v3i1.26

Funding: This study received no specific financial support.

History: Received: 4 November 2019/Revised: 19 December 2019/Accepted: 31 December 2019/Published: 8 January 2020

Licensed: This work is licensed under a Creative Commons Attribution 4.0 License $($ (c) $)$ EY

Acknowledgement: Both authors contributed to the conception and design of the study.

Competing Interests: The authors declare that they have no conflict of interests.

Transparency: The authors confirm that the manuscript is an honest, accurate, and transparent account of the study was reported; that no vital features of the study have been omitted; and that any discrepancies from the study as planned have been explained.

Ethical: This study follows all ethical practices during writing.

\section{Introduction}

According to Nigeria sovereign investment authority (NSIA 2018) report; Zea mays is the third staple food after wheat and rice in Afghanistan [1]. This crop is used in many agricultural industries. This plant has more protein than rice [2]. Based on the amount of production and area under cultivation, maize is one of the three most important cereals (wheat, rice and maize) among the producing countries. In Afghanistan maize yield per capita of land is lower than in other maize producing countries [3]. The main reason is using unappropriated dose of fertilizer, especially nitrogen [4]. Nitrogen is a key ingredient for producing chlorophyll and enzymes activities in crops [5]. Nitrogen is effective in absorbing many important nutrients such as potassium and phosphorus, which the proper amount of these elements cannot be effectively used in plant nitrogen deficiency conditions [6]. Therefore, nitrogen deficiency reduces maize yield. Crops requirement for nitrogen-varies from 150 to $240 \mathrm{~kg} \mathrm{ha}^{-1}$ [7]. There are many factors that effect on nitrogen requirement of maize such as irrigation, varieties used and soil fertility [3]. It is reported that use of nitrogen fertilizer is efficient to increase the quantitative and qualitative yield $[8,9]$. About $200 \mathrm{~kg} \mathrm{ha}^{-1}$ nitrogen fertilizer is reported efficiently for proper yield of maize [10]. In 1998 and 2001 it was concluded that increase in rate of nitrogen fertilizer absolutely will increase yield of maize 
$[11,12]$. In Egypt $160 \mathrm{~kg} \mathrm{ha}^{-1}$ nitrogen fertilizer is reported efficient for maize [5]. So, the aim of this study was to investigate the proper rate of nitrogen fertilizer for increasing yield of maize under Balkh province climate.

\section{Materials and Methods}

The experiment was applied in agricultural research farm of Balkh University in 2019 spring by applying the randomized complete block design (RCBD). Balkh province has a warm and dry climate which is very hot in summer and very cold in winter. Average of precipitation in Balkh province is $300 \mathrm{~mm}$ per year. Soil of area was tested in soil laboratory of agriculture faculty by kjelden machine and flame photometer made of China 2005 and provide by Joint Development Association organization (JDA), the characteristics of soil are described in Table 1. First, the area prepared as well and divided into 12 plots. In this experiment; four treatments by 3 replications were applied (see Table 2) Potential seed (a hybrid variety of maize) provided by Halim company Nangarhar was used. Distance between rows was $75 \mathrm{~cm}$ and between plants was $20 \mathrm{~cm}$ and plots size were $5 \mathrm{~m} \mathrm{x} 4 \mathrm{~m}=20 \mathrm{~m}^{2}$. There were 5 rows in each plot. Distance between plots was $0.5 \mathrm{~m}$ and total size of experiment area was $292 \mathrm{~m} 2$.

In this experiment, nitrogenous fertilizer (urea) provided by Karwan-e-sabz Company in Balkh province was applied in three growth stages (3 leaf stage; one month after germination, flowering and one month after flowering) while after plots were well irrigated. All agronomic operations in every plot were same except applying fertilizer. In this experiment height of 10 randomize plants were measured and other parameters such as number of grains in 10 cobs in every plot, cobs per plant, length of cobs and diameter of cobs were measured. Data analyze was done by SAS software version 2016 and effect of treatments was tested by LSD (least significant differences).

Table-1.

Shows soil characteristics of research farm.

\begin{tabular}{c|l|r}
\hline No & Soil Physical/Chemical Characteristics & Measures \\
\hline 1 & Soil Type & Silty Loam \\
\hline 2 & Soil Density & $1.21 \mathrm{gr} / \mathrm{cm}^{3}$ \\
\hline 3 & $\mathrm{pH}$ & 8.1 \\
\hline 4 & Electroconductivity & $0.6 \mathrm{~ms} / \mathrm{cm}$ \\
\hline 5 & Nitrogen amount & $14.0 \mathrm{ppm}$ \\
\hline 6 & Phosphorus amount & $47.1 \mathrm{ppm}$ \\
\hline 7 & Potassium amount & $152 \mathrm{ppm}$ \\
\hline 8 & Organic Matter $(\%)$ & \\
\hline
\end{tabular}

The soil density, metal cylinder made of 2018 Afghanistan was used. For measuring soil pH, the handy digital pHmeter (TOLED Company, India, 2013) was used. Soil electroconductivity was measured by EC-meter provided by spectrum Technology Company of India (2010). Finally the availability of nitrogen, phosphorus and potassium (NPK) were measured by NPK Soil Test Kit - HI3896 - Hanna Instruments, India 2009.

Table-2.

Shows treatments of experiment.

\begin{tabular}{|c|c|}
\hline Treatments & Dose of Urea \\
\hline Treatment 1 (Control) & $0 \mathrm{~kg} \mathrm{ha-1}$ \\
\hline Treatment 2 & $80 \mathrm{~kg}$ ha-1 \\
\hline Treatment 3 & $160 \mathrm{~kg} \mathrm{ha-1}$ \\
\hline Treatment 4 & 240 ha- 1 \\
\hline
\end{tabular}

Table-3

\begin{tabular}{|c|c|c|c|c|c|c|c|c|c|c|}
\hline $\begin{array}{l}\text { Source of } \\
\text { Variance }\end{array}$ & $\varrho$ & 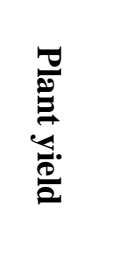 & 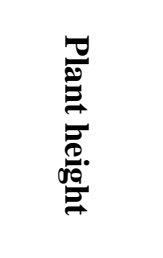 & . & 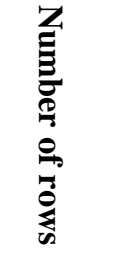 & 总 & 兽 & 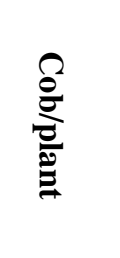 & 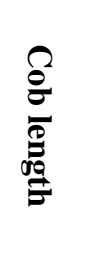 & 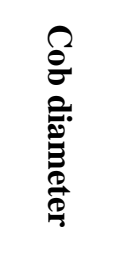 \\
\hline Replication & 2 & $1.254^{\mathrm{ns}}$ & $1093.12 * *$ & $7.38^{\mathrm{ns}}$ & $0.702^{\mathrm{ns}}$ & $1115.32^{\mathrm{ns}}$ & $191.68^{\mathrm{ns}}$ & $0.082^{\mathrm{ns}}$ & $9.26^{\mathrm{ns}}$ & $0.0071^{\mathrm{ns}}$ \\
\hline Treatment & 3 & $125^{* *}$ & $876.4^{\mathrm{ns}}$ & $194.97^{*}$ & $2.9^{\mathrm{ns}}$ & $853.63^{*}$ & $7129.15 *$ & $0.38^{\mathrm{ns}}$ & $32.5 *$ & $0.52 *$ \\
\hline Error & 6 & 20.63 & 981.03 & 95.43 & 3.154 & 156.63 & 21770.23 & 0.64 & 11.7 & 0.47 \\
\hline
\end{tabular}

Note: Represents the analyzed data of plant parameters.

** Shows significance at $1 \%$ level and * at $5 \%$ level $(\mathrm{P}<0.05)$ by Fisher's LSD, but ns shows non-significant level. 


\section{Results and Discussion}

Results showed that; there was just a significant difference between replications in plant height but the remain parameters had no significant difference in replications. In this experiment as treatments were in focused so, there were significant difference between treatments in all parameters (see Table 3). The increasing population of our country requires to produce more food, there the main food for our people is cereals and among them maize is the third crop. Therefore, one option to achieve this goal is to increase yield of this plant and one way is using $\mathrm{N}$-fertilizer [1]. As maize plant produces more dry matter so, for producing dry matter more nutrients are needed.

Comparing mean of parameters showed that the treatment with $240 \mathrm{~kg} \mathrm{ha}^{-1}$ urea was significantly effective in parameters such as plant height and grain per row, weight of grain per plant, grain per cob, cob length, and cob diameter treatment (see Table 4). Finally, as a main result it's to be mentioned that there was significant difference of plant yield between treatments (see Table 3 and Figure 1).

Table-4.

Represents grading of plant parameters.

\begin{tabular}{|c|c|c|c|c|c|c|c|c|c|}
\hline 急 & 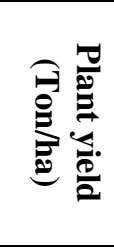 & 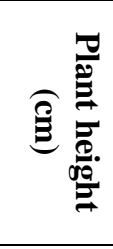 & 㿣. & 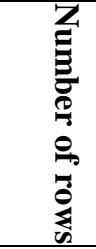 & 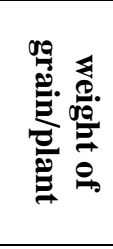 & 䁶 & 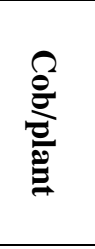 & 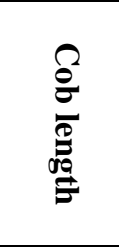 & 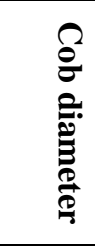 \\
\hline 0 & $5.12^{\mathrm{c}}$ & $181.0^{c}$ & $26.89^{c}$ & $16.0^{c}$ & $76.0^{\mathrm{d}}$ & $430.2^{\mathrm{d}}$ & $2.00^{\mathrm{d}}$ & $147.0^{\mathrm{d}}$ & $38.0^{c}$ \\
\hline 80 & $6.46^{b}$ & $196.0^{c}$ & $196.0^{c}$ & $16.2^{\mathrm{c}}$ & $95.0^{\mathrm{c}}$ & $3175.2^{\mathrm{c}}$ & $3.30^{\mathrm{c}}$ & $153.0^{\mathrm{c}}$ & $40.0^{\mathrm{b}}$ \\
\hline 160 & $7.43^{\mathrm{a}}$ & $199.8^{b}$ & $199.8^{\mathrm{b}}$ & $16.5^{\mathrm{b}}$ & $105.2^{\mathrm{b}}$ & $3296.7^{b}$ & $4.55^{\mathrm{b}}$ & $160.1^{\mathrm{b}}$ & $42.2^{\mathrm{ab}}$ \\
\hline 240 & $7.76^{\mathrm{a}}$ & $204.6^{\mathrm{a}}$ & $204.6^{\mathrm{a}}$ & $18.6^{\mathrm{a}}$ & $107.0^{\mathrm{a}}$ & $3805.5^{\mathrm{a}}$ & $6.70^{\mathrm{a}}$ & $167.2^{\mathrm{a}}$ & $44.5^{\mathrm{a}}$ \\
\hline
\end{tabular}

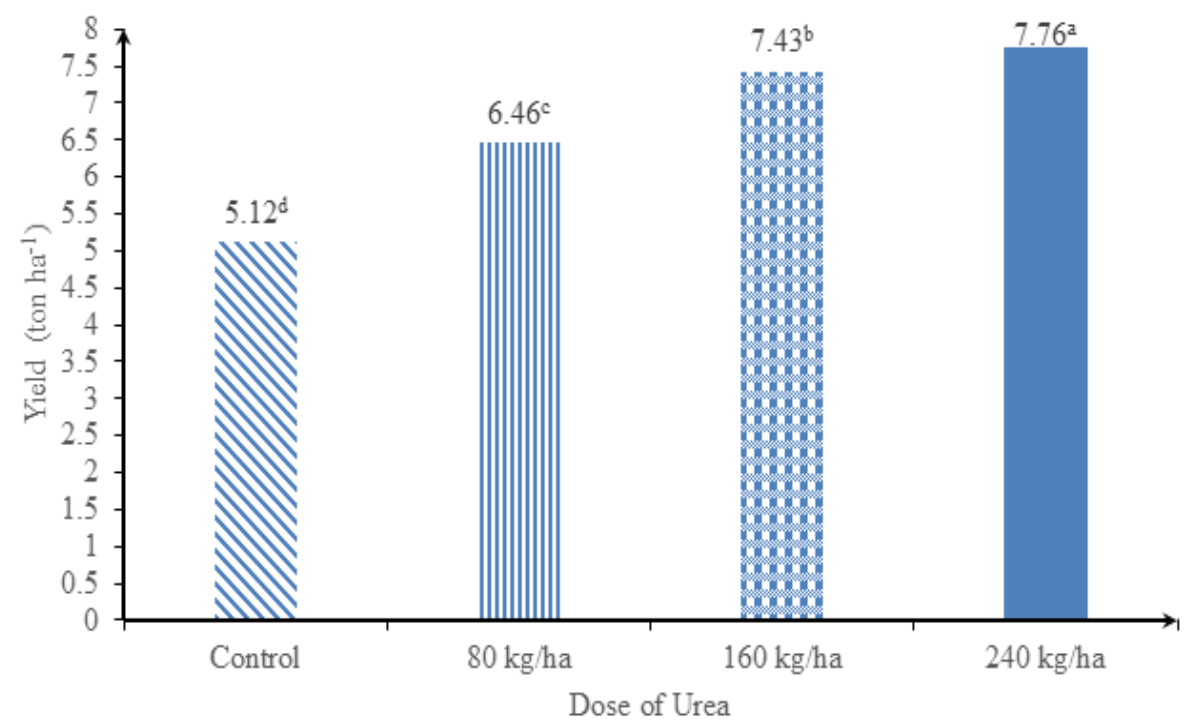

Figure-1.

Yield of maize in all treatments.

\section{Conclusion}

In this experiment, nitrogen fertilizer had positive effect on yield maize. Yield of maize was increased with increasing amount of nitrogen fertilizer. The highest grain yield was recorded in the highest amount of nitrogen fertilizer $\left(240 \mathrm{~kg} \mathrm{ha}^{-1}\right)$ and the lowest yield was observed where no nitrogen fertilizer was used (Treatment 1). So, treatment 4 is recommended for highest yield.

\section{References}

[1] NSIA, "Nigeria sovereign investment authority survey report. Nigeria," pp. 12-14, 2018.

[2] K. Sanjeev, A. Bangarwa, and S. Kumar, "Yield and yield components of winter maize (Zea mays L.) as influenced by plant density and nitrogen levels," Agricultural Science Digest, vol. 17, pp. 181-184, 1997.

[3] L. Bundy and P. Carter, "Corn hybrid response to nitrogen fertilization in the Northern Corn Belt," Journal of Production Agriculture, vol. 1, pp. 99-104, 1988. Available at: https://doi.org/10.2134/jpa1988.0099.

[4] C. Brady, The nature and properties of soils. New York: Macmillan Publishing Company, 1984. 
[5] F. T. El-Sheikh, "Effect of soil application of nitrogen and foliar application with manganese on grain yield and quality of maize (Zea mays L.)," in Proceedings of the 8th International Conference. Agron., Suez Canal Univ., Ismailia, Egypt, 28-29, 1998, pp. 174-181.

[6] R. B. Khot and N. K. Umrani, "Seed yield and quality parameters of American tail maize as influenced by spacing and level of nitrogen," Indian Journal of Agronomy, vol. 37, pp. 183-184, 1992.

[7] F. Tetio-Kagho and F. Gardner, "Responses of maize to plant population density. I. Canopy development, light relationships, and vegetative growth," Agronomy Journal, vol. 80, pp. 930-935, 1988. Available at: https://doi.org/10.2134/agronj1988.00021962008000060018x.

[8] G. Hardas and M. Aragiaanne-Hrestous, "Long-term fertilizer trial in the Kopais area with a two-year rotation of maize and wheat, I: The effect of N," P and K Application on Yield, Georgike Ereuna, vol. 9, pp. 89-90, 1985.

[9] M. S. Zeidan, A. Amany, M. Bahr, and F. El-Kramany, "Effect of N-fertilizer and plant density on yield and quality of maize in sandy soil," Research Journal of Agriculture and Biological Sciences, vol. 2, pp. 156-161, 2006.

[10] D. Singh, N. Rana, and R. Singh, "Growth and yield of winter maize (Zea mays) as influenced by intercrops and nitrogen application," Indian Journal of Agronomy, vol. 45, pp. 515-519, 2000.

[11] M. Samira, A. Hussein, M. Haikel, and M. El-Masry, "Effect of some preceding crops, hill spacing and nitrogen fertilization on yield attributes and grain yield of maize under reclaimed sandy soil conditions in East Delta," in Proceedings of the 8th International Conference, Suez Canal Univ., Ismailia, Egypt, 1998, pp. 28-29.

[12] H. A. Torbert, K. N. Potter, and J. E. Morrison, "Tillage system, fertilizer nitrogen rate, and timing effect on corn yields in the Texas Blackland Prairie," Agronomy Journal, vol. 93, pp. 1119-1124, 2001. Available at: https://doi.org/10.2134/agronj2001.9351119x. 